\title{
Eschatologies, and future-looking reminiscence
}

\begin{abstract}
Traditionally, authors of memoir, life writing, and autoethnography have used prose to tell their stories, with the occasional image to supplement their narratives. In the multimedia age some life writers are turning to art, photography, design and technology to increase the scope of their research and writing. In turn, such authors have created new authorial identities and become graphic-authors, artist-scholars, or even bricoleurs. Writing for artist-authors takes on a more Derridean flavour, and comes to incorporate all manner of meaning-making inscriptions, including images, design, and non-verbal elements. Readers, too, become active rather than passive, challenged to read against traditional left-to-right reading gravity and to navigate between different textual elements (as they do online). Readers become viewers and participants, and the text shifts from 'readerly' to 'writerly' in the Barthesian sense. Consequently, authors are designing new hybrid forms of life narrative for on-screen viewing rather than on-page reading; in other words, for digital rather than paper forms of dissemination and authorship. As screen-based visual-verbal constructions, art(e)facts combine art, virtuality and facts to create evocative critical-creative bricolages.

Keywords: graphic life writing, autoethnography, artist-scholars
\end{abstract}

Dr Andrew Miller is a Senior Lecturer in multi-literacies at Flinders University. He is the author of Raging Against the Mass-Schooling Machine: An Autoethnography of a Beginning Teacher (2017). Andrew's research interests include graphic texts, creative non-fiction, autoethnography, and critical and creative approaches to research. His work challenges the prose-centrism of traditional research by incorporating images and design into its meaningmaking process. Andrew supports the expansion of the term writing to include non-verbal and graphic elements as readily as it currently embraces words and prose. Andrew has published critical and creative work in Wet Ink, TEXT, Creative Approaches to Research, English in Australia, Liminalities, and New Writing: The International Journal for the Practice and Theory of Creative Writing. Contact: andrew.miller@flinders.edu.au

\section{TEXT}

Vol 21 No 2 October 2017

http://www.textjournal.com.au

General Editor: Nigel Krauth. Editors: Kevin Brophy, Enza Gandolfo \&

Julienne van Loon

text@textjournal.com.au 


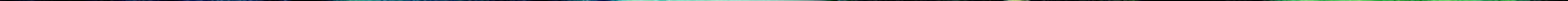





\section{3}

These pages will be my reveries. I my-
formless record of $m$ in them, because
self will figure largely in thins a lot about a solitary person inevitably thinks a lot about himself. But all the other will also have their place through my mind will also have thought just as it here. I shall say came to me.

(Jean-Jacques Rousseau, Reveries of the Solker, 1792/1979: 32)

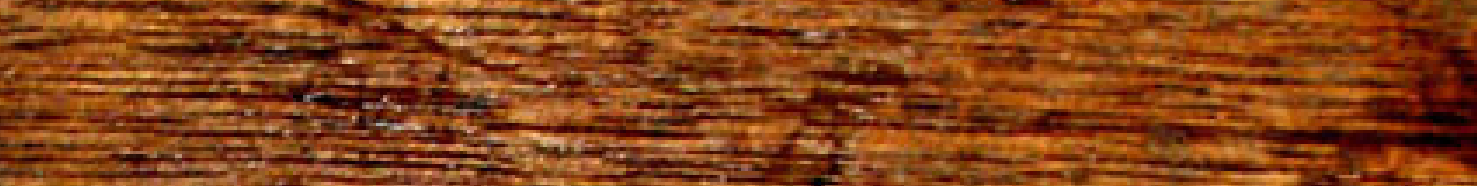

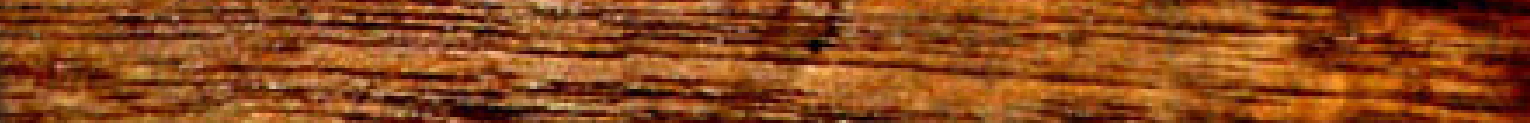
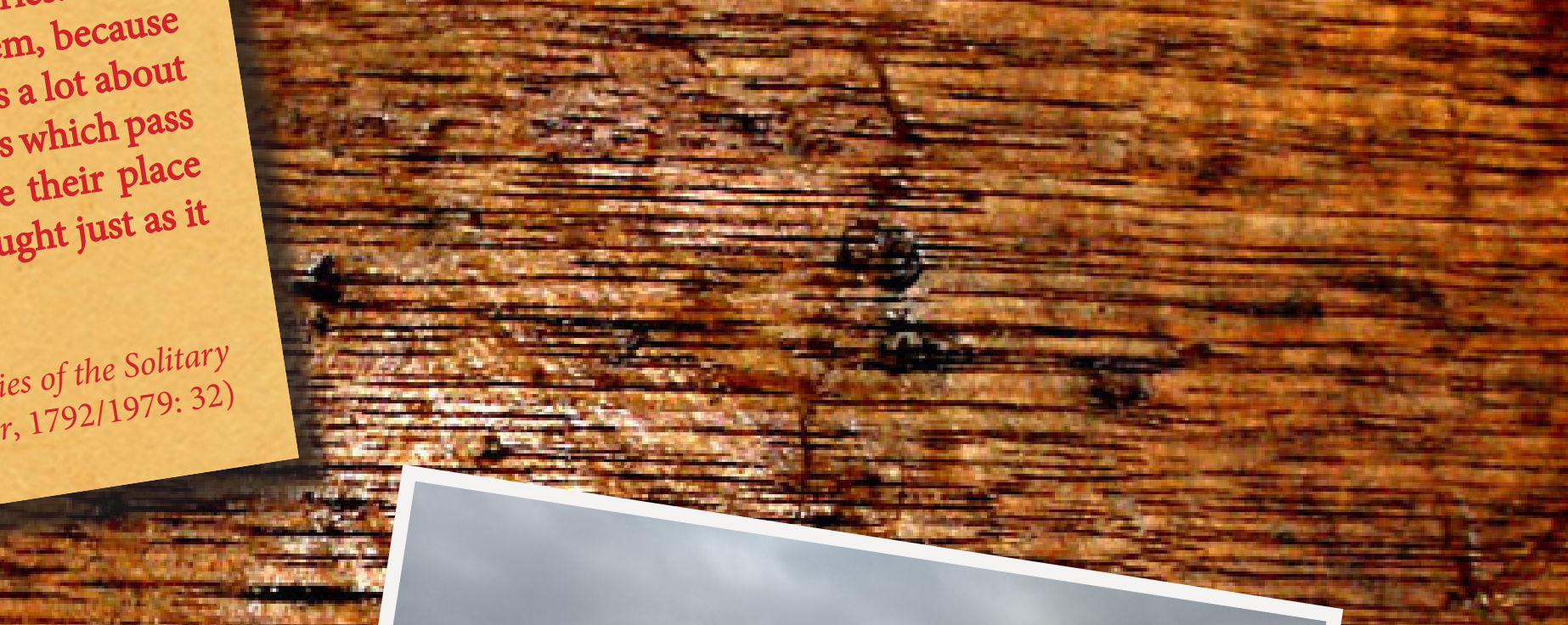

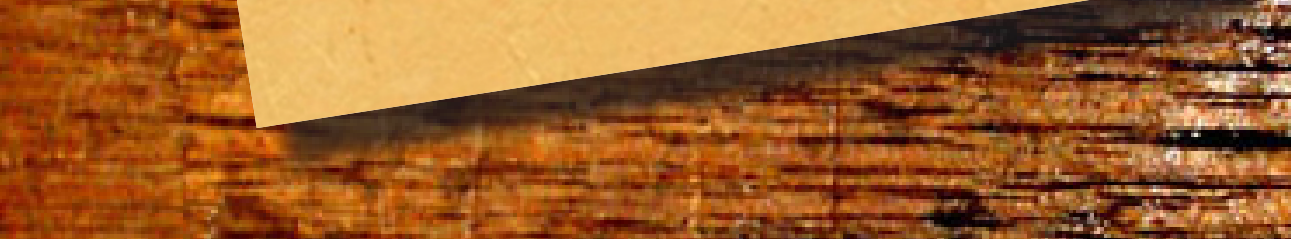

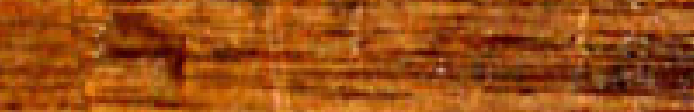

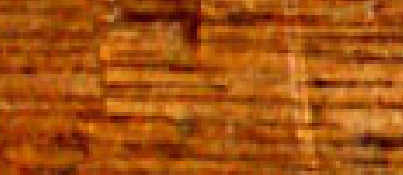




\section{Abstract: Multimodal Art(e)facts}

Traditionally, authors of memoir, life writing, and autoethnography have used 'prose' to tell their stories, with the occasional illustration or image to supplement their narratives. In the multimedia age some life writers are turning to art, photography, design, and technology to increase the range and scope of their research and 'writing. In turn, such authors have created new authorial identities and become graphic-authors, artist-scholars, or even bricoleurs. Writing for artist-authors takes on a more Derridean flavour, and comes to incorporate all manner of meaning-making inscriptions, including images, design, and nonverbal elements. Readers, too, become active rather than passive, challenged to read against traditional left-to-right reading gravity and to navigate between different textual elements (as they do online). Readers become viewers and participants, and the text shifts from 'readerly' to 'writerly' in the Barthesian sense. Consequently, authors are designing new hybrid forms of life narrative for on-screen viewing rather than on-page reading; in other words, for digital rather than paper forms of dissemination and authorship.

New technologies are making such multimedia bricolages possible. Visual-verbal bricoleurs can now write beyond prose by making use of multimodal and screen-based methods of dissemination and viewing. This adheres with Derrida's ideas on 'picto-ideo-phonographic' writing, where multiple registers, discourses, and visual elements are woven together to form tripartite (or polyphonic) texts. Images, narratives, and critical commentaries merge to extend the text's meaning-making potential, and to present the life narrative in new and hybrid ways.

This text combines words and images-design and discourse-to create the first instalment of a screen-based 'graphic memoir bricolage' that takes research beyond prose and beyond paper and into the aesthetic and digital. It also takes the author away from being a paper-based prose-writer to a screen-based bricolage-writer. As life writers and artists (who 'write' with visual, verbal, and nonverbal elements), such authors occupy both 'author'

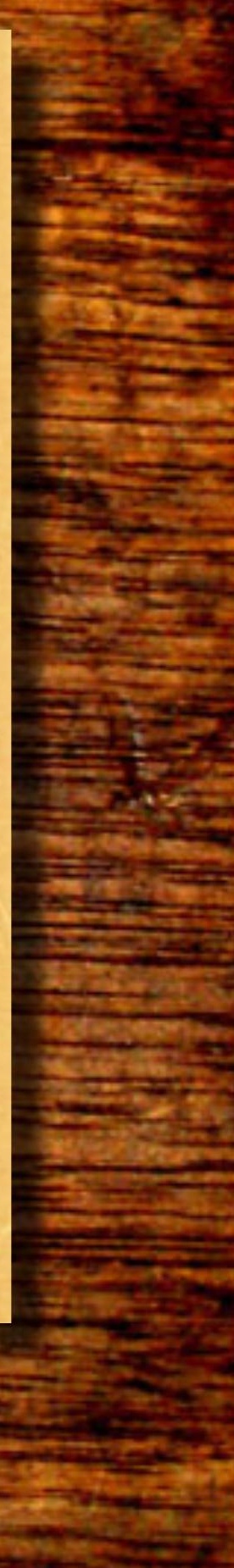




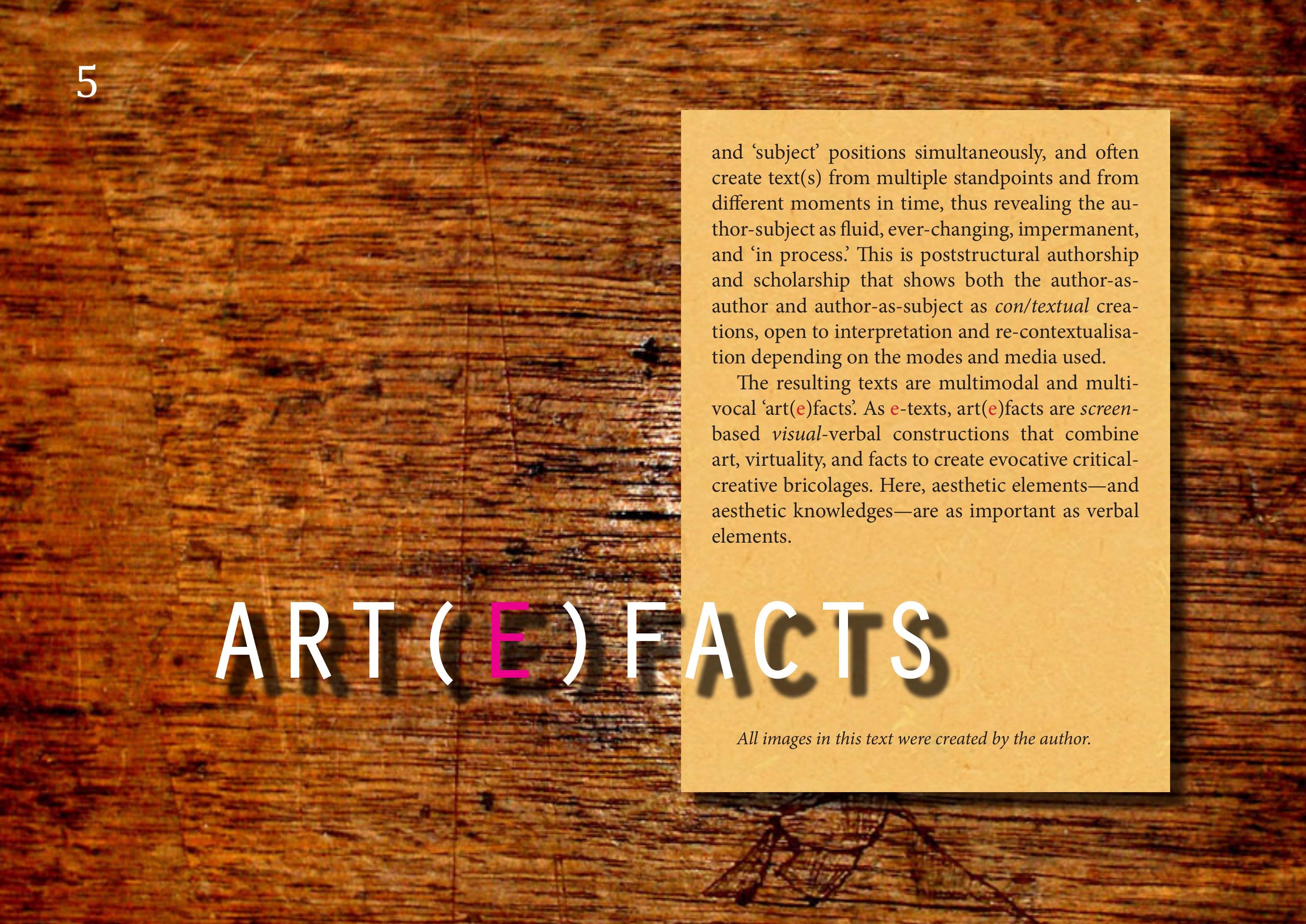




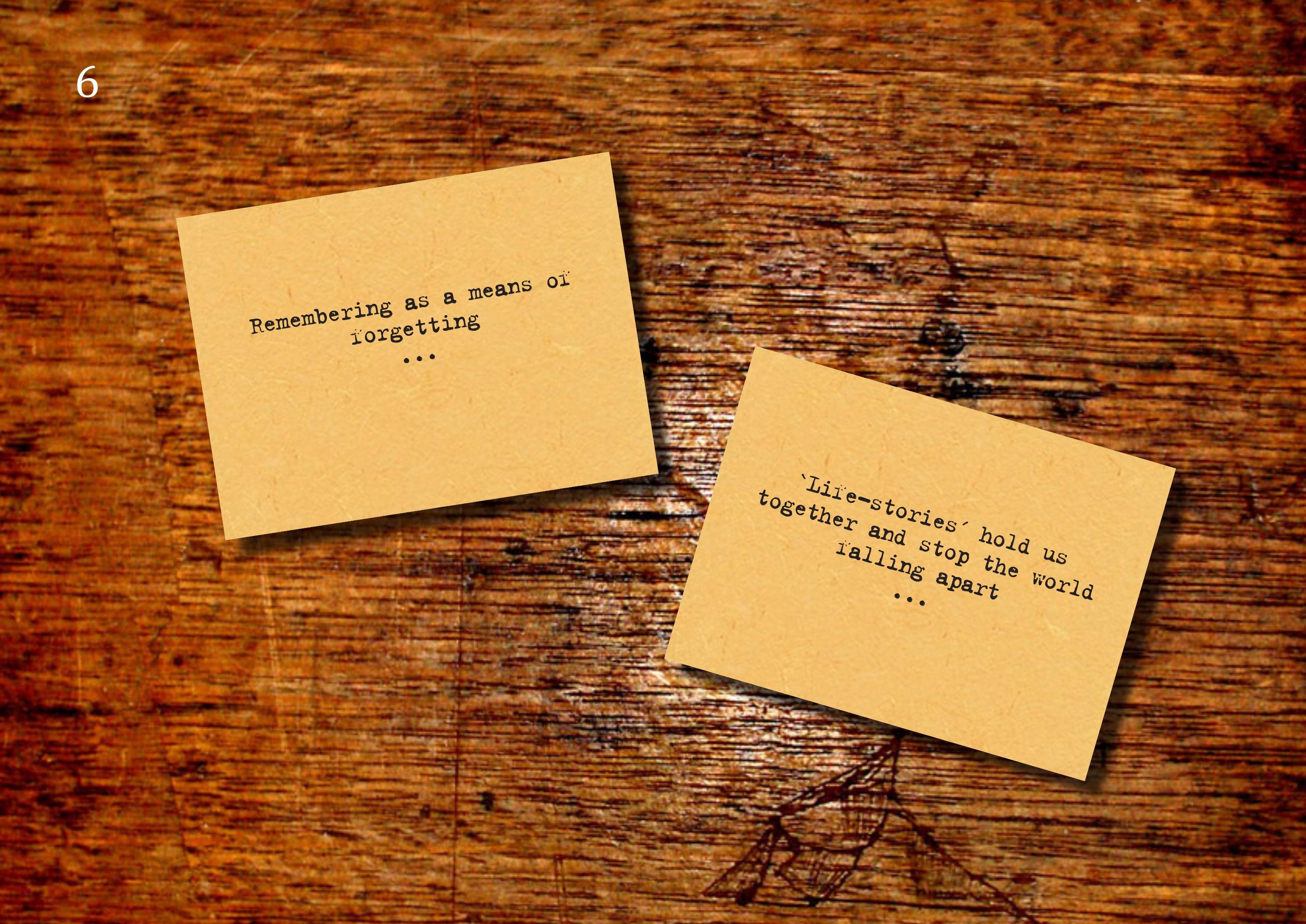




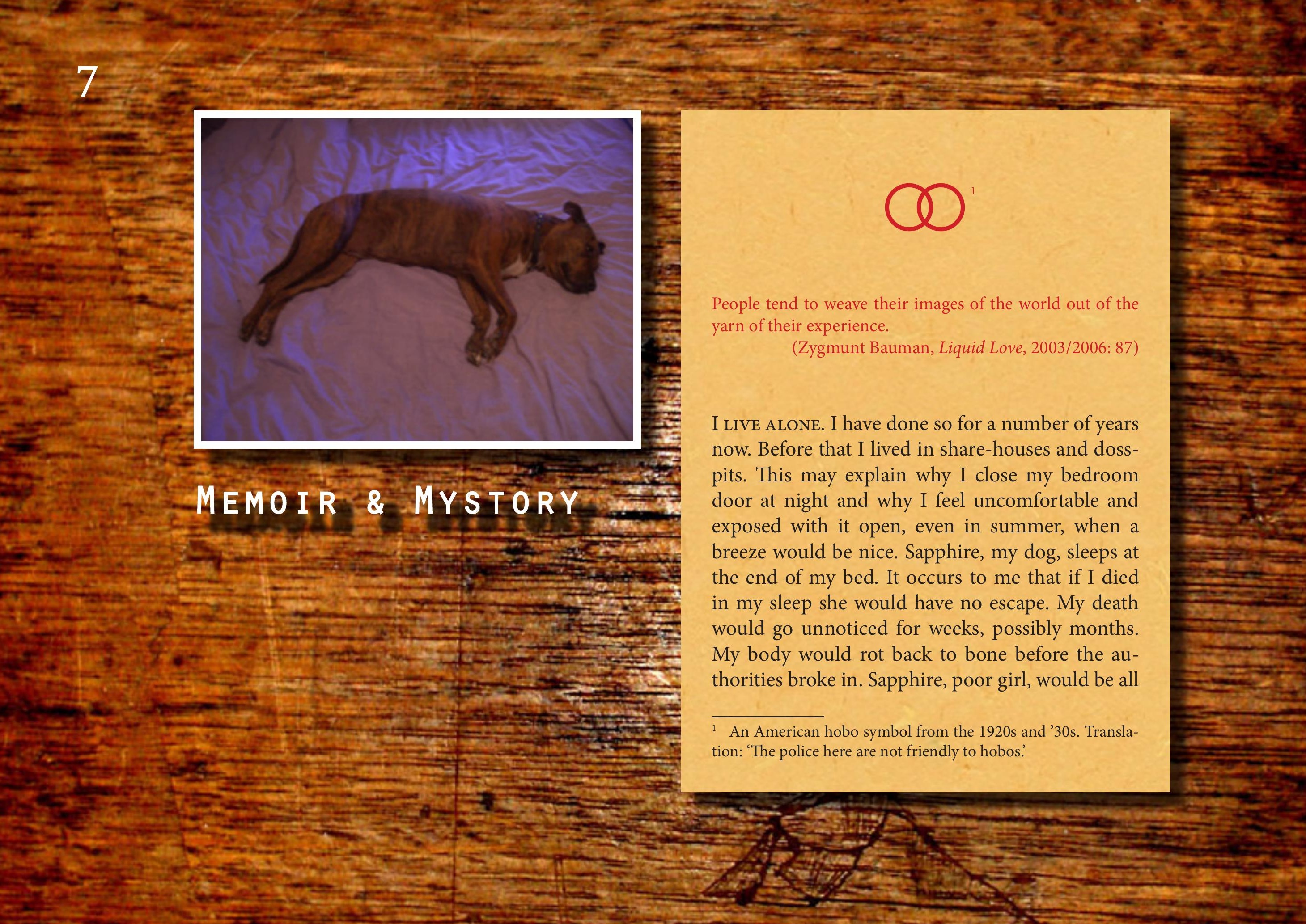


Shine on you crazy diamond.

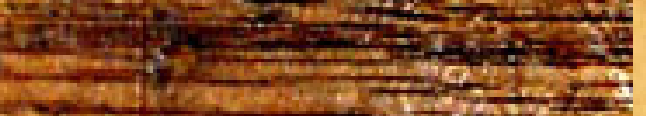

alone and entombed. She too would die. Her death would be slow and gruelling-drawn-out, agonising, thirsty, hungry, and lonely. How many days would she nudge at my head before nibbling at my ears? Before crying out and moaning at the emptiness? Would she drink my blood and eat my heart? Would she scratch the door to shreds and her paws to bone? Would she bark at the night until hoarse and defeated? Ahooooooo-

I hate to think. But even if I did leave my bedroom door open her prospects for survival would hardly improve. She could drink from the toilet to stave off thirst, but eventually her food would run out. My flesh would fade. Shit would pile up. Piss would sink in. The stench of decomposing dog would replace the stench of decomposing human.

Ahooooooo-

Even still, this is no way to start a memoir. Memoirs usually dwell on past experiences rather than dream about future horrors. 'Future nostalgias' are usually the morbid luxury of eschatologists and doomsday prophets, not damp-eyed memoirists and self-obsessed megalomaniacs. Unless, of course, you take the view that memoirs capture the

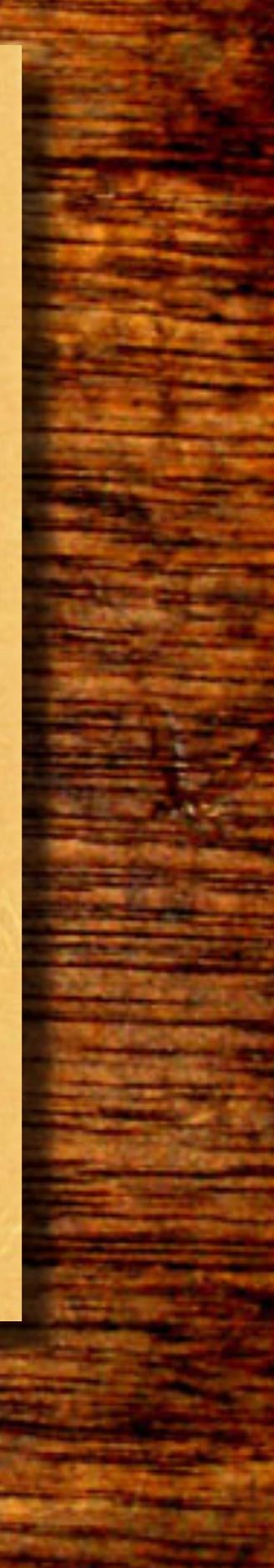




\section{$=9$}

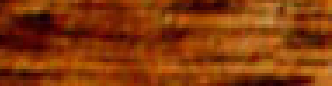

An autobiography promises feats worthy of record, conversations with famous people, a central role in important events. There is none of that here. At the-very least, an autobiography implies a summing up, a certain closure, that hardly suits someone of my years, still busy $=$ charting his way through the world. Finally, there to are the dangers 4 inherent in any autobiographical work: the temptation to color events
in ways favorable
to the writer. to color events.
$=z$
in ways favorable
to the writer. the tendency to overestimate the interest one's = experiences hold for others, selective lapses of memory. 'fragments' of life while autobiographies capture the 'whole' of life, in which case reflections on the perversities that go on 'inside' the head are just as permissible as the heroic feats that go on 'outside' the head. I'll take the view that neither memoir nor autobiography can actually capture life, either in part or in full, and instead take the view that both endeavours merely represent possible versions of life, in part or in full. On a different day, in a different context, using a different perspective, in a different mood, a different story would be told. It all depends on how the story is told and who or what is included and ignored. One 'life' could mushroom into multiple lives-one 'self' into multiple selves. And all would be true. As Paul Carter notes in The Road to Botany Bay (1987: 142-143), '...the true dialogue the writer conducts is not with external reality, but with language itself'; that is, with what Jacques Derrida calls the 'undecidability' of language and the 'free play' of signs (i.e. polysemy). Carter continues:

We clarify our ideas by setting them out. By covering the previously clear page, we give our un-

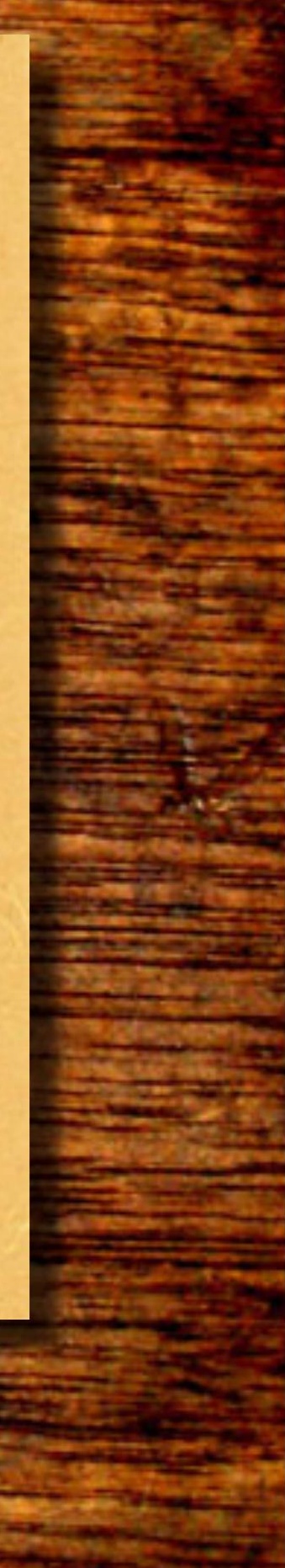




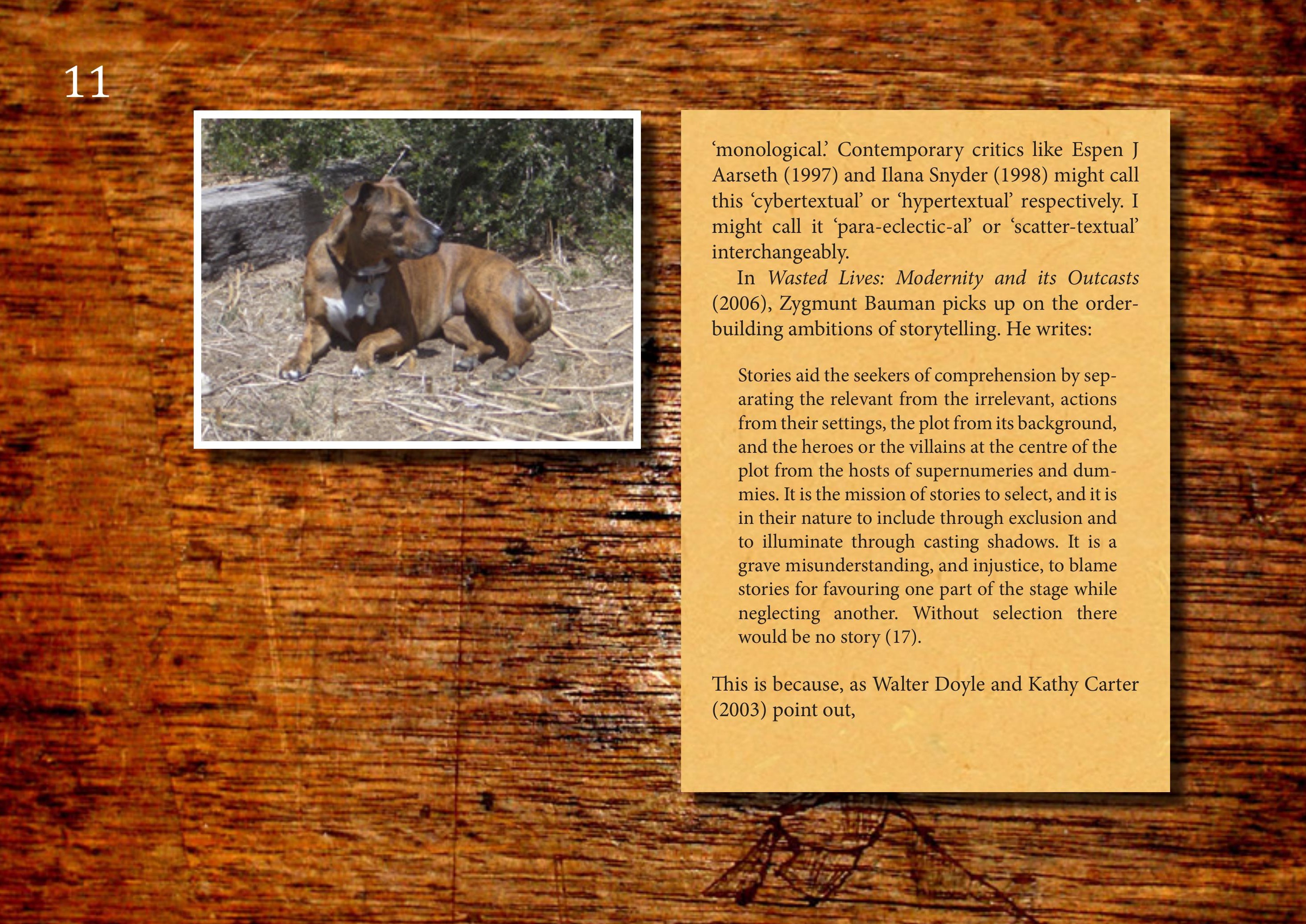




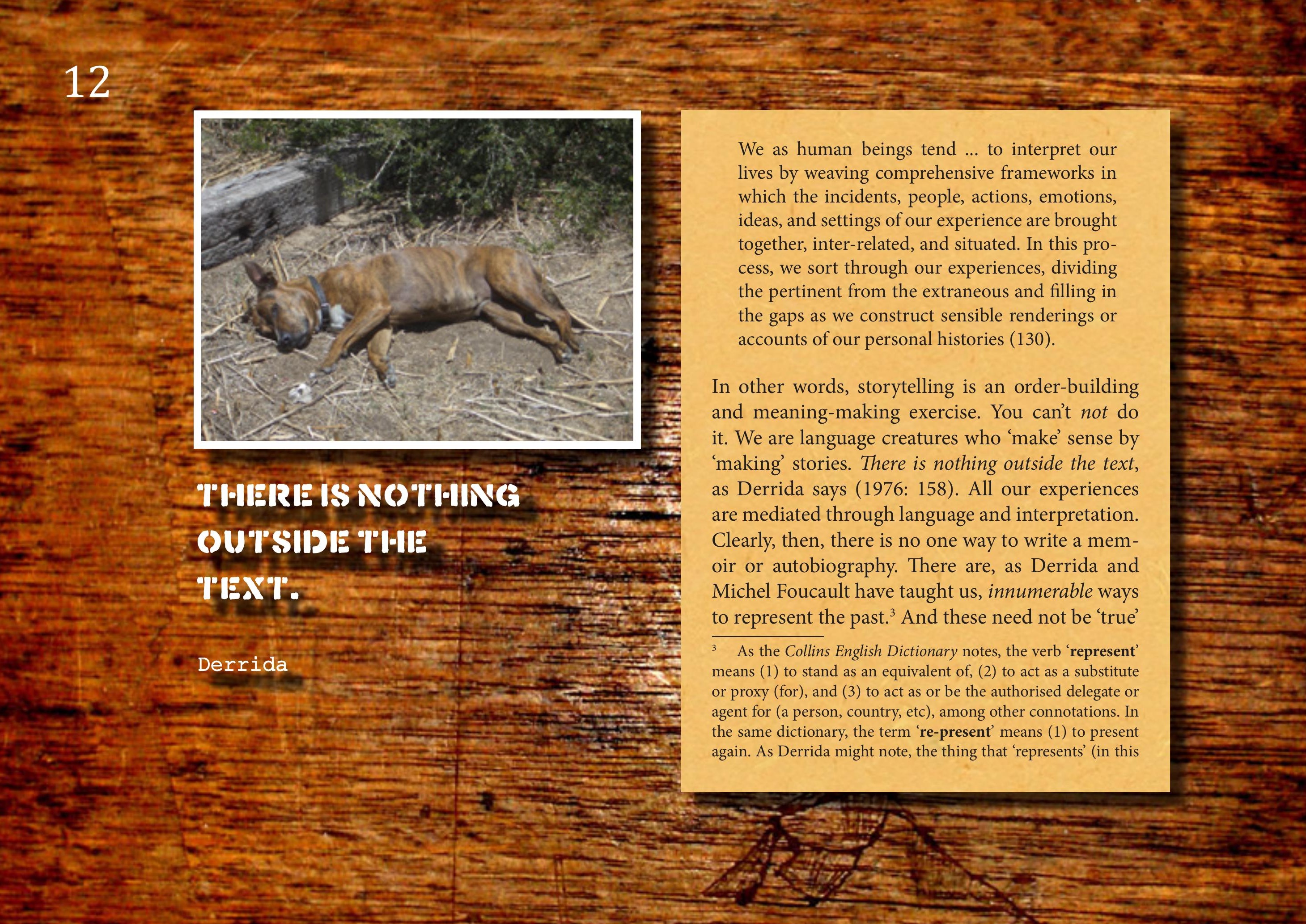




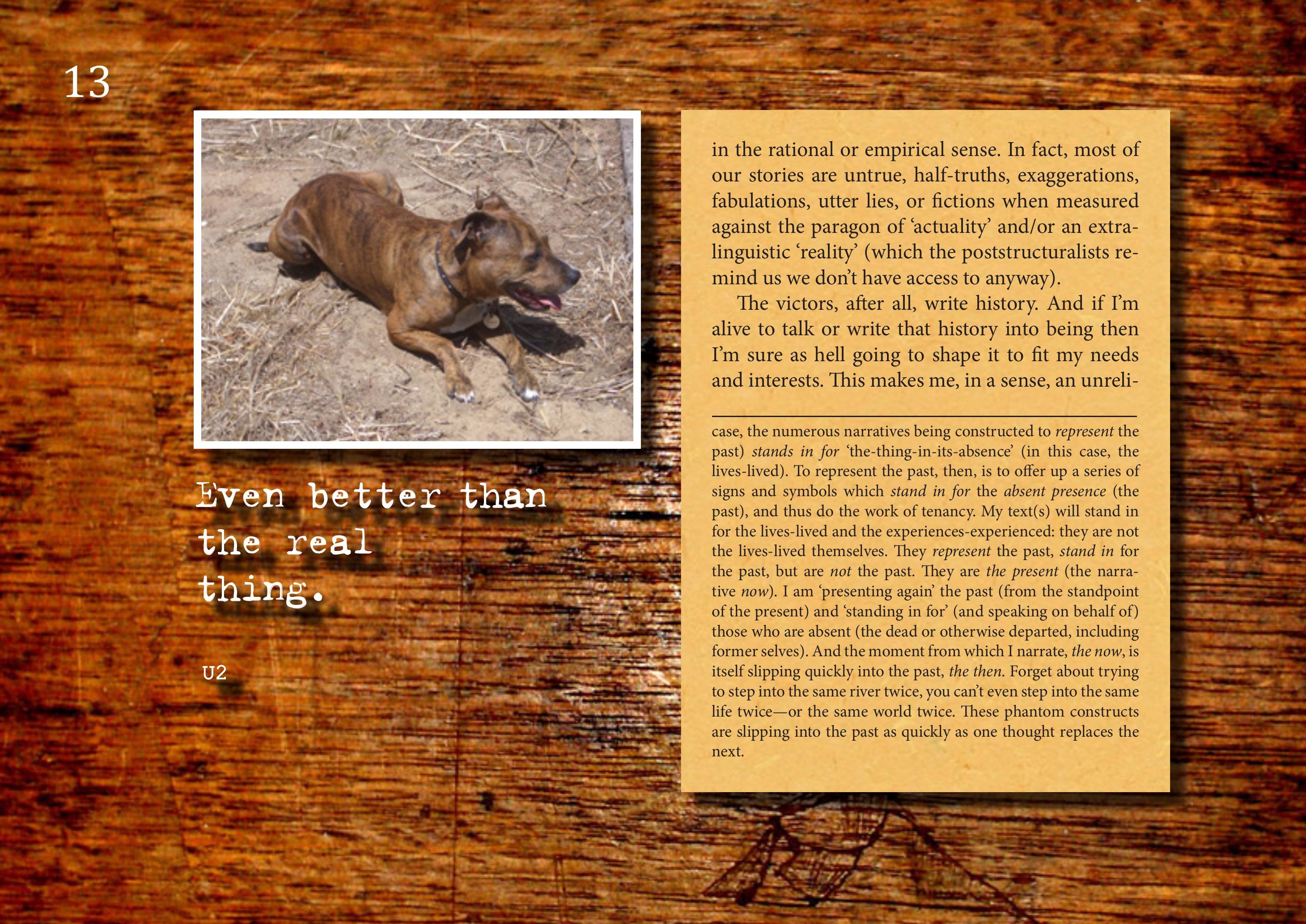


able and hostile witness. After all, consciously or unconsciously, I will conceal as much as I reveal. I'll soften my defects and talk up my assets. And somehow, by some means, these makeshift versions of history will be 'truer' than their originals. They will be 'hyper-real', as Jean Baudrillard might say, or more real than real. Simulacra histories: even better than the real thing (as U2 have sung). As infamous underworld hit man Mark 'Chopper' Reid proudly suggests, don't let the truth stand in the way of a good story - particularly when your post-prison career relies on writing books and telling yarns that embellish your past life.

This text is no exception. It fights as much with language and representation as it does with memory, reflexivity, ego, incompetence, bias, and the context in which it is produced (i.e. the modernist institution which makes it almost impossible to think and act outside the existing prose-centric, answer-insistent, project-directed, order-dependent 'structured' paradigm). It won't attempt to write or perform one story or one truth, but multiple stories and multiple truths. Like Doris Lessing's The Golden Notebook (1962), the fragments will hope-

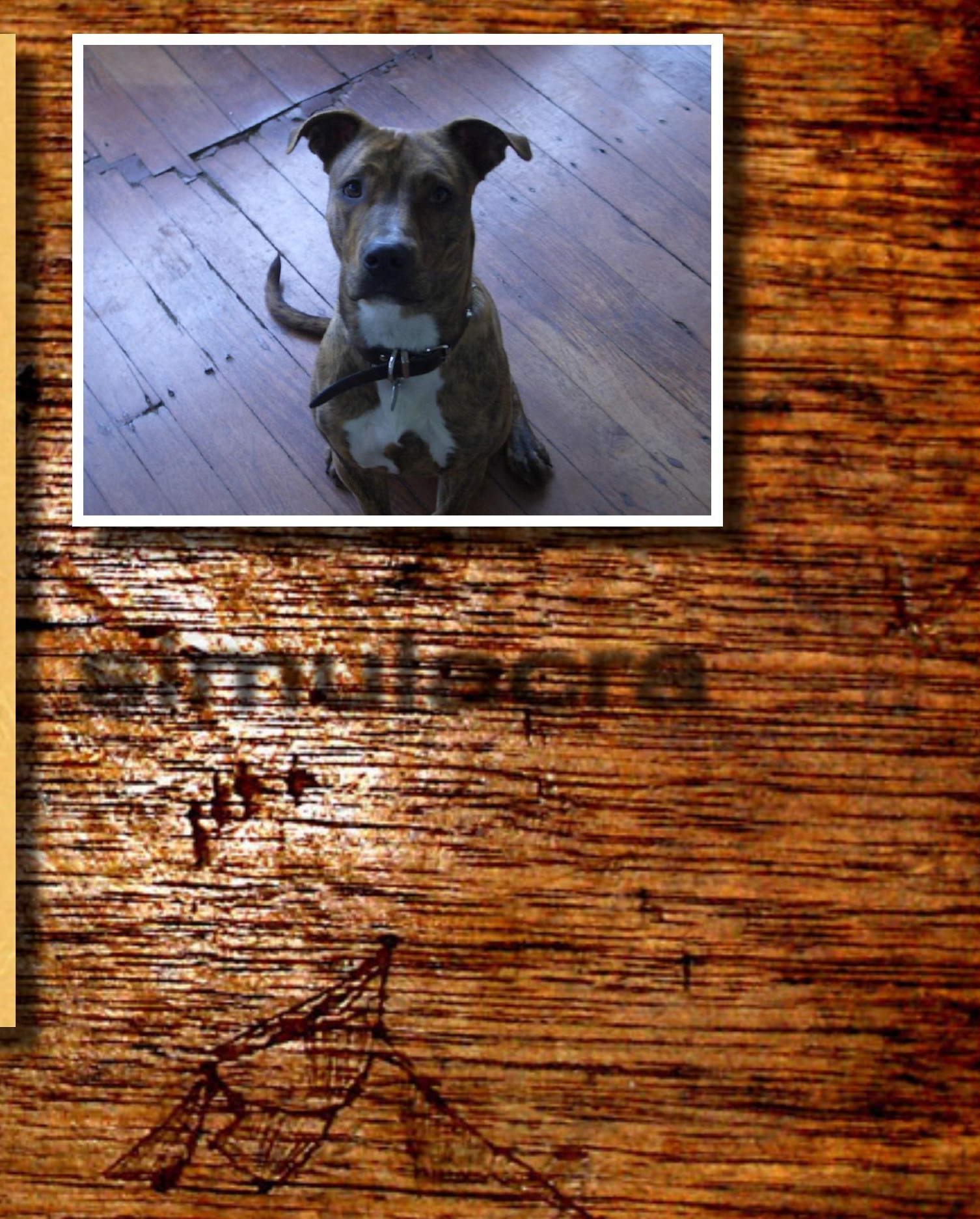




\section{5}

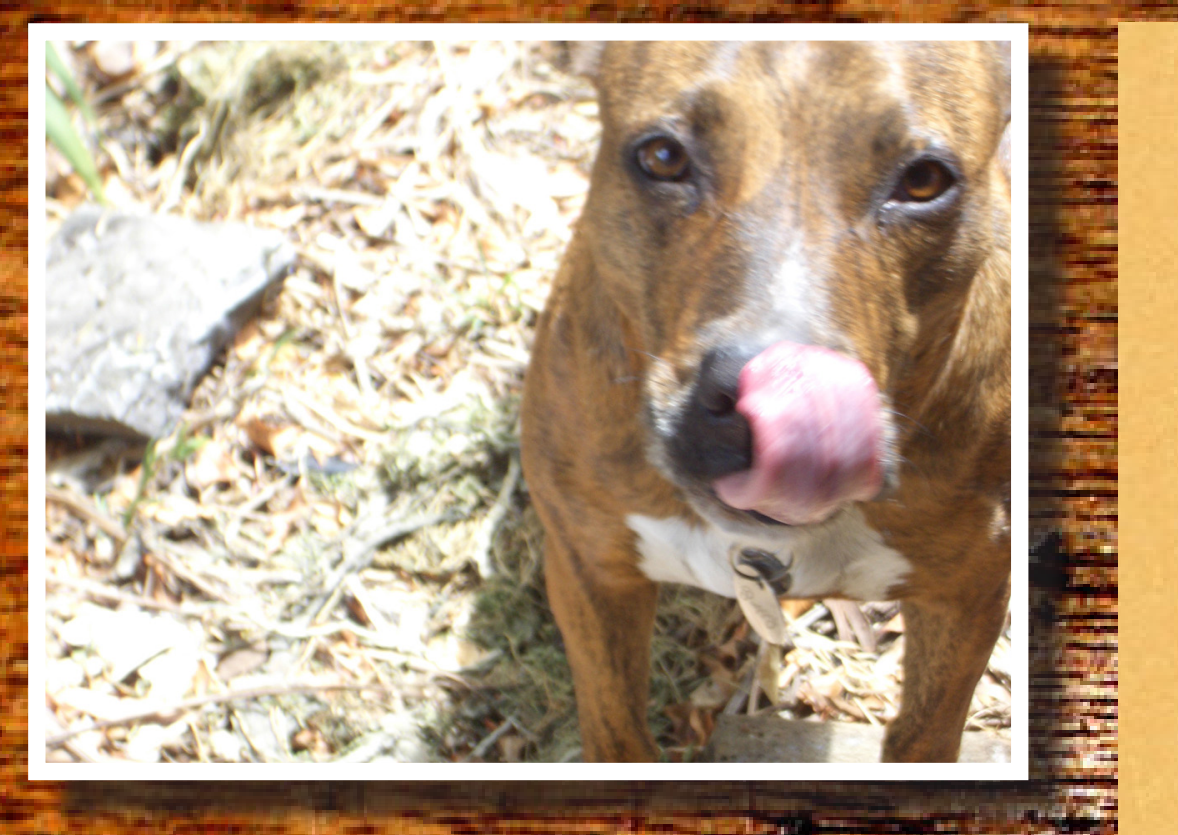

fully converge to tell another story, a bigger story, a more accurate and false story. The various narrative threads and episodes will form a bricolage of life, an incomplete and thorough account of past and future memories and imaginings. I am writing to find out who I am (and who I might become) and where I've been (and where I might go). I am writing my identity into being rather than pretending to capture a pre-existing subject. No such subject or history exists. I am inventing my 'selves' as I go along, even past selves and past histories.

As Janette Turner Hospital points out in The Last Magician (1992), the past is never finished: it lies in wait, just ahead. It is a story we keep writing and inventing from cradle to grave. The past keeps bobbing up in the present, every bit as 'real' as its original, and the ghosts of yesteryear keep crowding our heads and speaking our names. While I'm talking to you I'm talking to my dead dad. Ahooooooo - I'm both present and absent from this moment and that moment. I have a foot in every day I've ever lived.

At the 2008 Adelaide Writers' Week, Robyn Davidson suggested that 'The past is not sealed, 


\section{7}

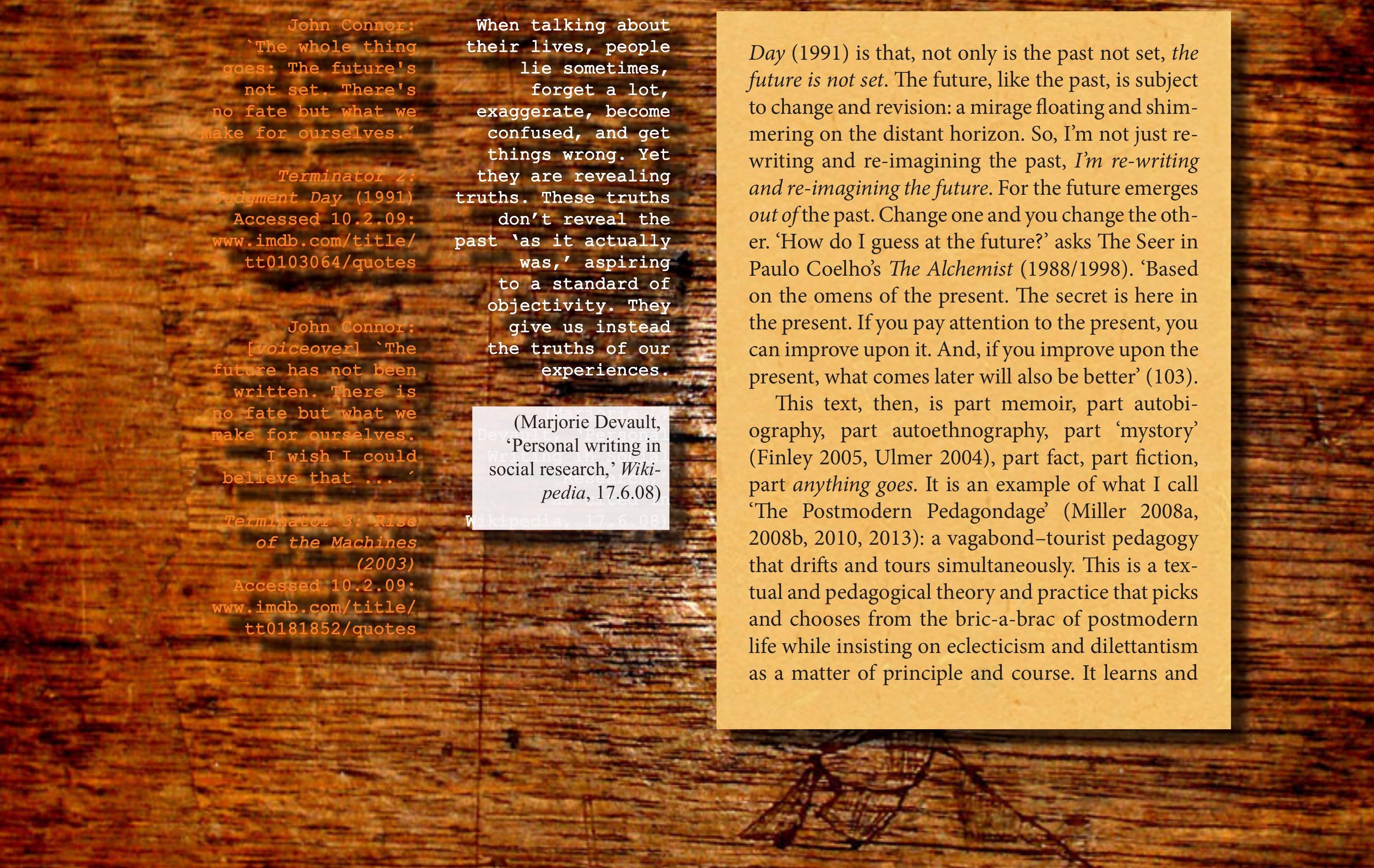




\section{8}

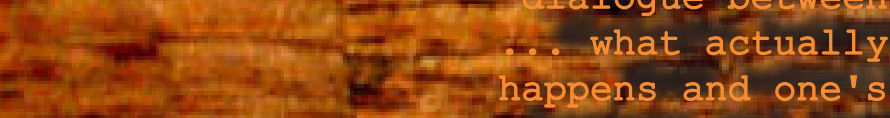
tet- 20 own interpretation 7 - 3 of what actually

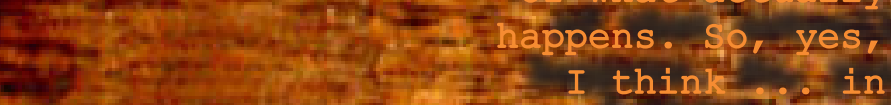

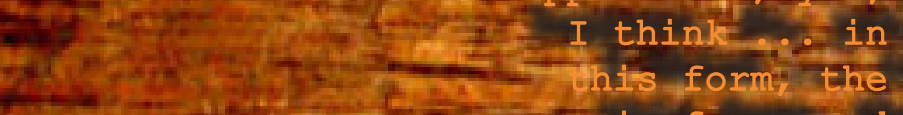

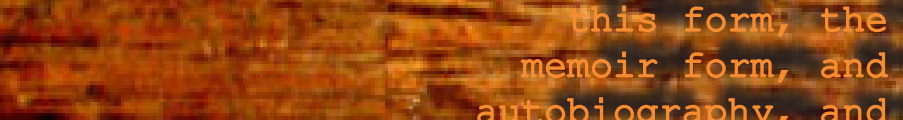
Er 3 autobiography, and

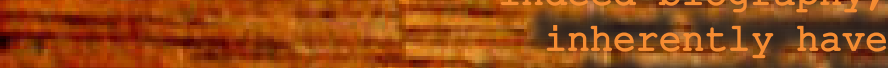

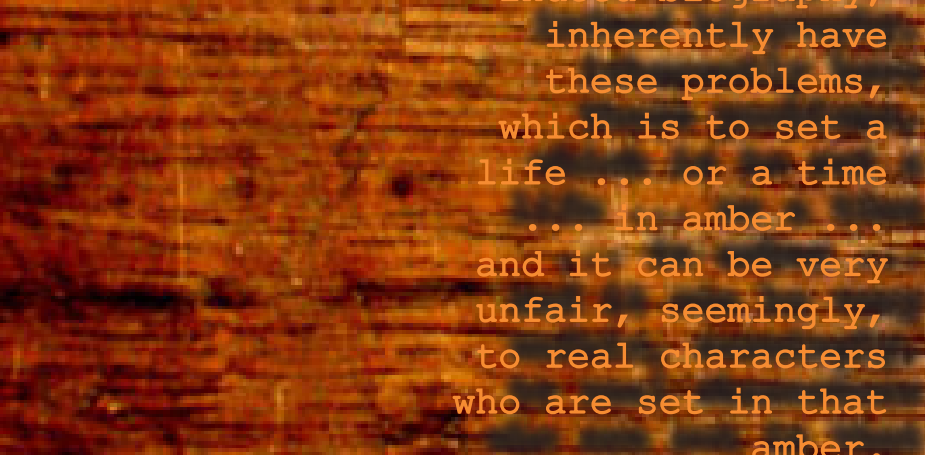

Memory selects, and interprets and what is to be selected and how it needs to be interpreted is a moot matter and an bject of continuous contention. The resurrection of the past, keeping the past alive, can only be attained through the Hective, choosing, treprocessing and $\frac{t}{5}$ recycling, work of

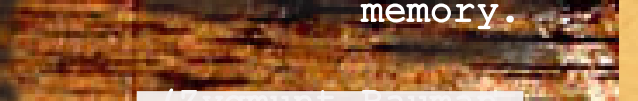
(Zygmunt Bauman, Liquid Love, 2006:

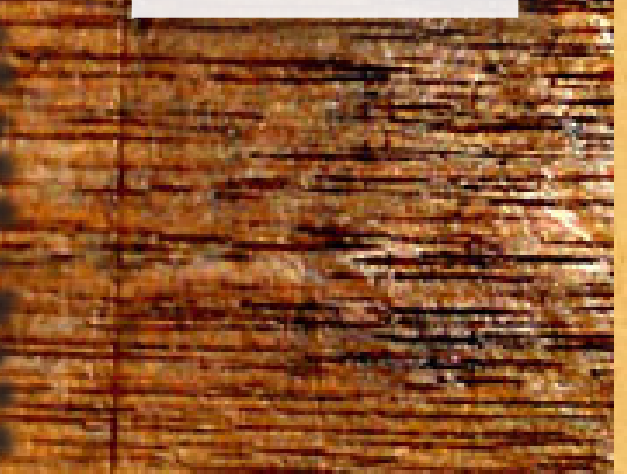

unlearns in equal measure. It forgets and remembers simultaneously. It welcomes creative digressions and spontaneous asides every bit as much as it plans packaged tours and structured holidays. It creates and disrupts and builds and destroys. In this sense it draws inspiration from the creative and transgressive feats of 'travel' writers like Frank Moorhouse (Room Service) and Bruce Chatwin (In Patagonia and The Songlines); picture book authors like Matt Ottley (Requiem for a Beast), and Gary Crew and Peter Gouldthorpe (The Lost Diamonds of Killiecrankie); and discursive essayists like Michel de Montaigne (Essays), Jean-Jacques Rousseau (Reveries), and Henry David Thoreau (Walden). These authors do not follow one road or one argument or one plot. Their texts are simultaneously structured and un-structured and planned and unplanned. They are neither essays nor novels in the 'monological' sense. These writers and artists leave the path and enter the scrub. They cross borders and mix genres. They keep their options open, as Zygmunt Bauman (Wasted Lives, 2006: 107) might say, and are ready and willing to turn left rather than right and backward rather than forward as 


\section{9}

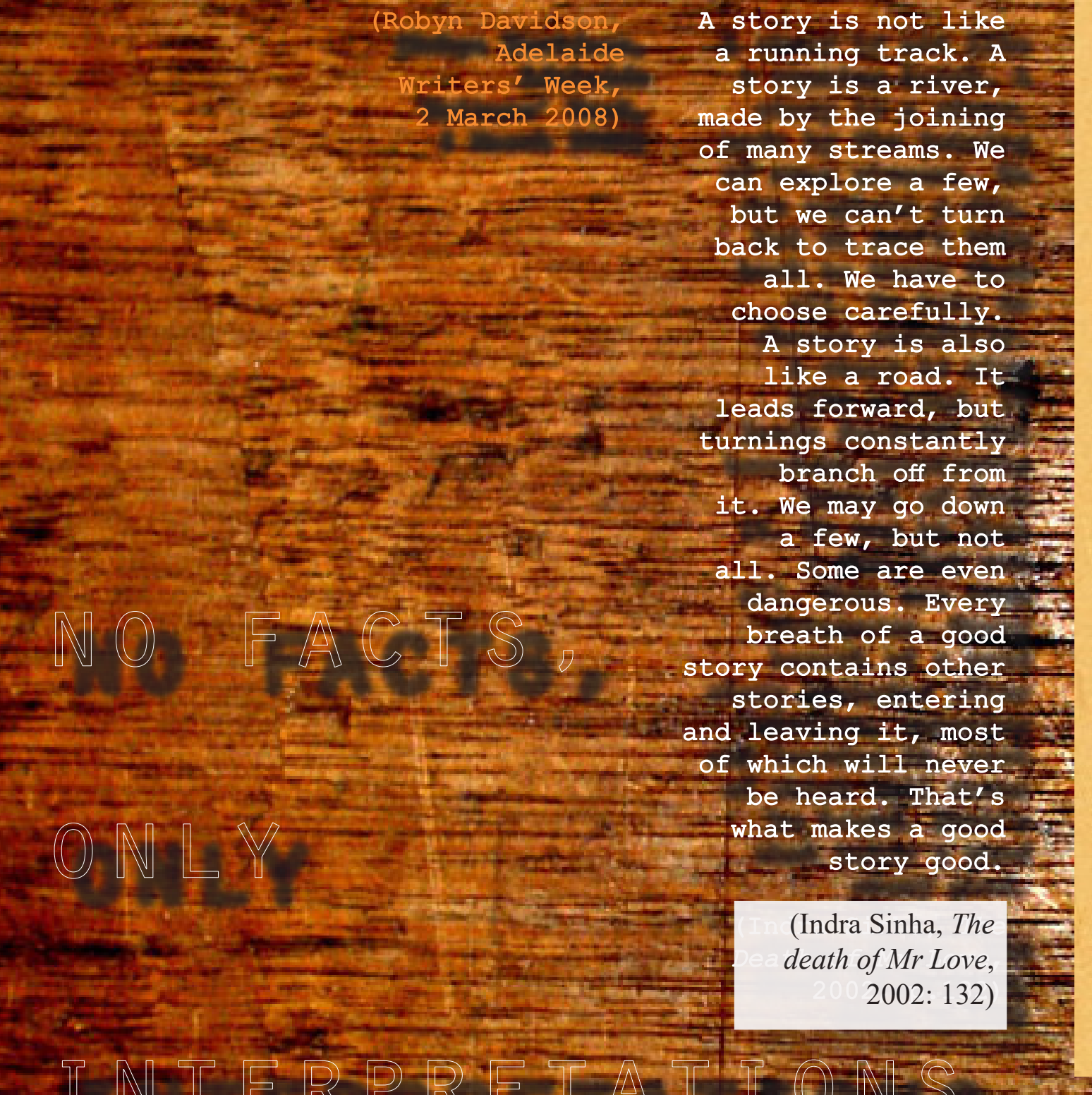

whim will have it. Itineraries change. Interests peak and wane. Bricoleurs know that just as many stories turn up in the sewers and back streets of hell as on the boulevards and terraces of utopia, and that the stories of beggars and vagabonds can be every bit as compelling as those of tycoons and tourists. One man's truth is another woman's lie. As Nietzsche says, there are no facts, only interpretations, and travel writers know that all journeys and all stories are provisional. Until-further-notice.

This text is as much a recount as it is a future imagining. It is an eschatological memoir and future-looking reminiscence. And this is as it should be-neither here nor there-neither then nor now. It is a simulacra memoir. A copy of a copy of a lie. Of a truth.

Ahooooooo-

So let's start again. Let's pray I don't die in the night and trap Sapphire in hell. Let's pray I install a trapdoor so she can escape if need be. And let's pray I leave ample food by the backdoor to tide her over until help arrives. Just as I did Santa and his reindeers as a child.

So let's start somewhere else, somewhere nearer
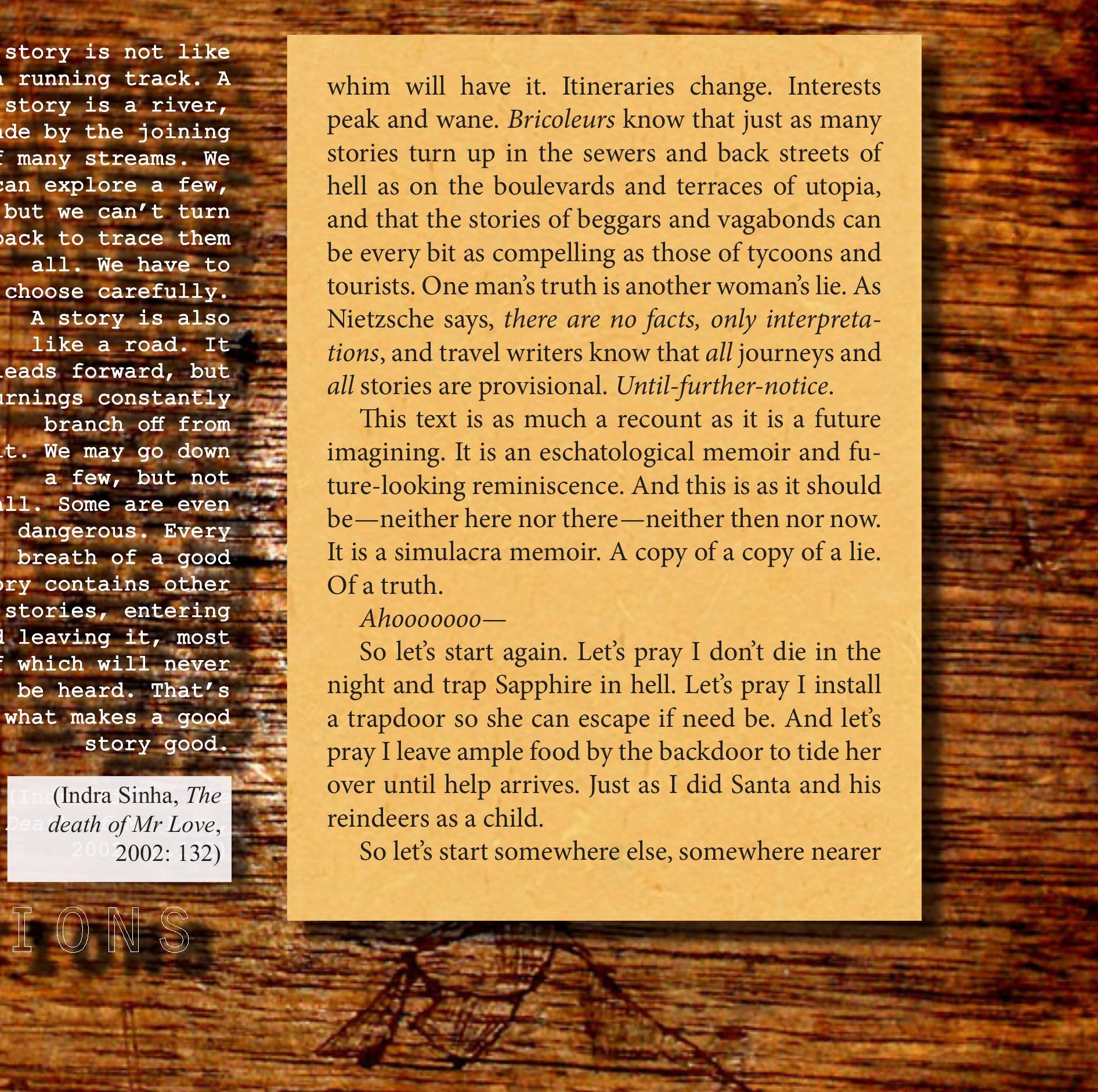


\section{0}
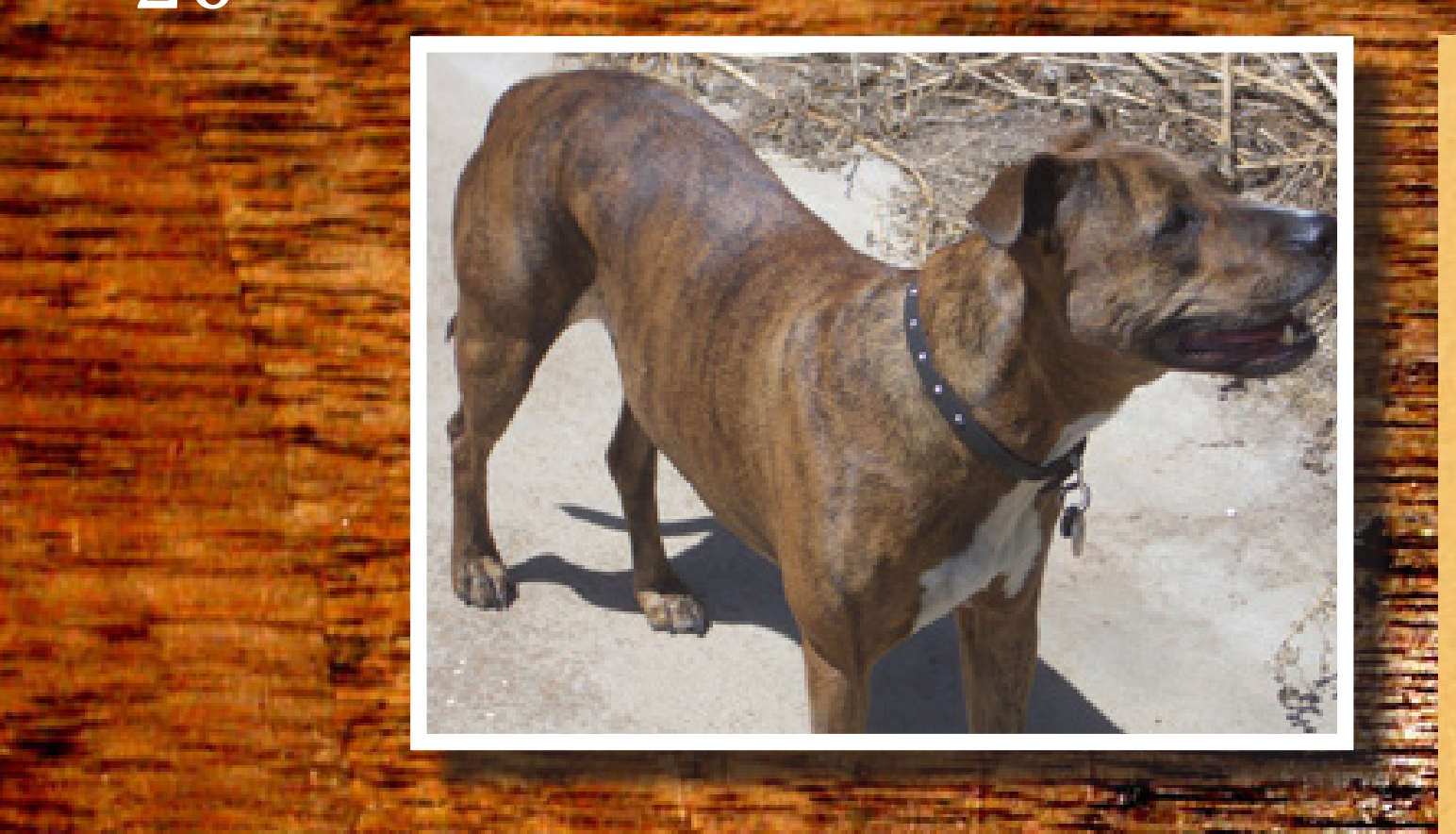

$110000000=$

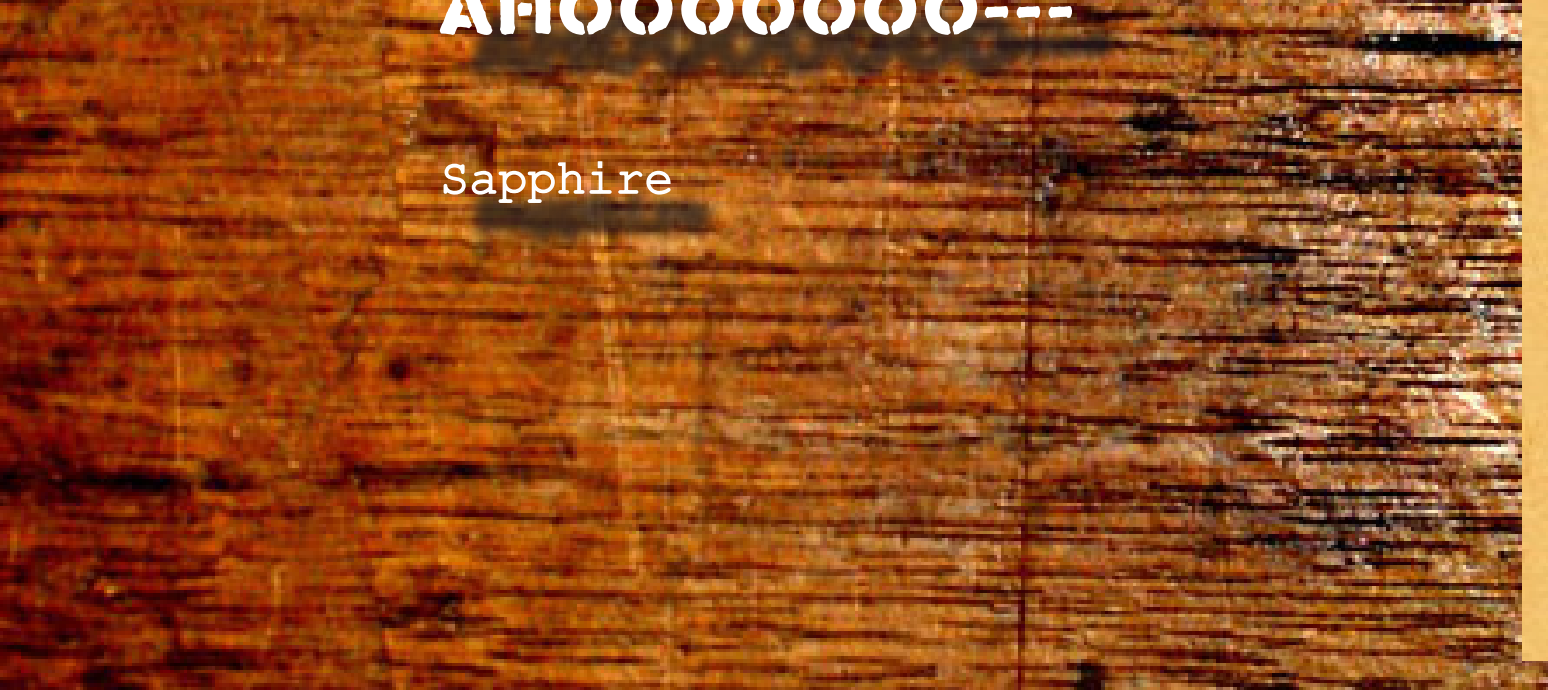

truth than fantasy, somewhere nearer the beginning than end. Let's start, as they say, in medias res, in the middle of things, and turn away from this troubling room and troubling aside.

So let's begin by playing somewhere else.

Let's begin by leaving...

Let's start somewhere else.

Eschatology: 'The part of theology concerned with death, judgement, and the final destiny of the soul and of humankind' (Oxford English Dictionary).

Let's start in another world-in another dimension-in a parallel life.

Many years have passed since I wrote the first lines of this text. And much has changed. I no longer leave my bedroom door closed at night and Sapphire no longer sleeps at the foot of my bed. She has grown old, and blind, and deaf, and frail. I spent so much time imagining and fearing her death that her demise came to me, like a delayed echo, only sharper and more graphic. Her deterioration has, in fact, matched my own transformation. Sadly, her diminishing has matched some-

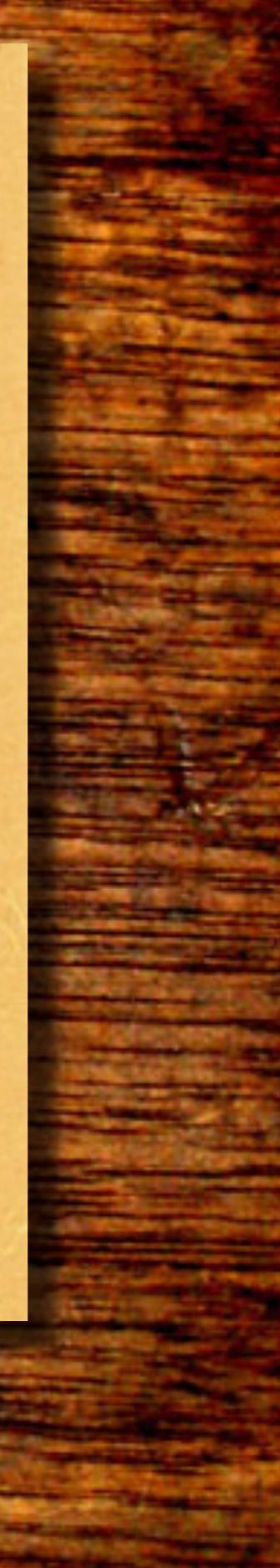




\section{1}

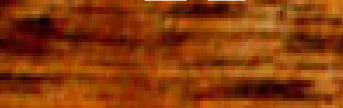

Are we not as pebbles in the stream of fate, now washed together in some sandy bay, then scattered along the margin and then dispersed? And when the rain of time. descends and swells the stream we are 4-arwept before the mat 1 tide, some over cascades, some in deep bedded poolsine some on shore, and $=$ some are hurried away until lost in the ocean of Eternity. This is 4 . the life of man. (William-Anderson ti

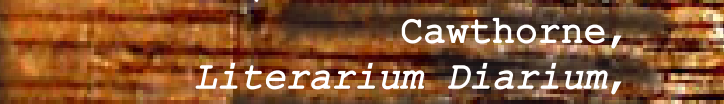
Literarium Diarium,
Whit

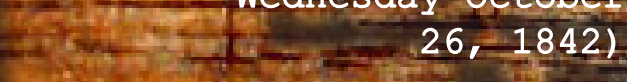

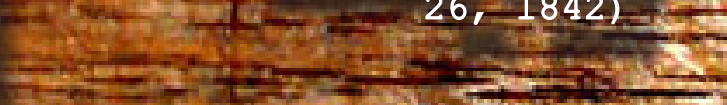
For.

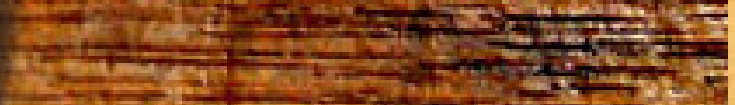

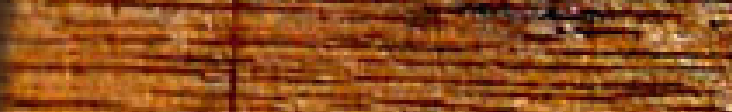

thing like my replenishing. My beginning. And I feel bad about that.

The end of one world has led to the beginning of another. One life fades while another shines.

My door is open because we need to hear the baby. She is two now, and the fitful and sleepless nights have given way to longer and quieter slumbers. Kate sleeps beside me. She has made a home, a family, an us. She didn't just make a new entityshe made a new world.

Sapphire moved outside, with our other two dogs, when our daughter arrived. She was new and they were boisterous. Things had changed. I built a three-room dog kennel beside the house, and the dogs repay us with fits of barking at the kangaroos and foxes that slouch and slink through the surrounding night. We live on a two-acre block with vegetable gardens, newly-planted fruit trees, mature eucalypts, and revegetation. We built an off-grid house. We make our own power and collect our own water. We recycle our own septic and keep our own chickens. We grow as much food as we can and we watch the seasons pass through the leaves and sky. The shadow of our daughter grows

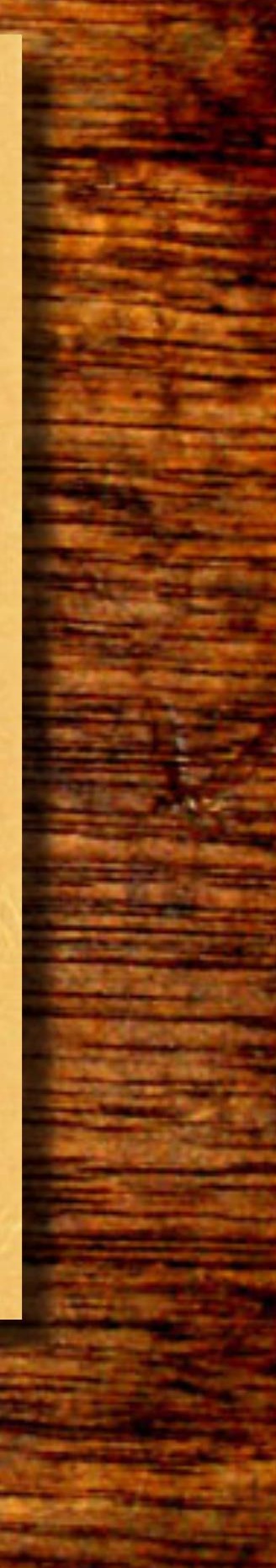




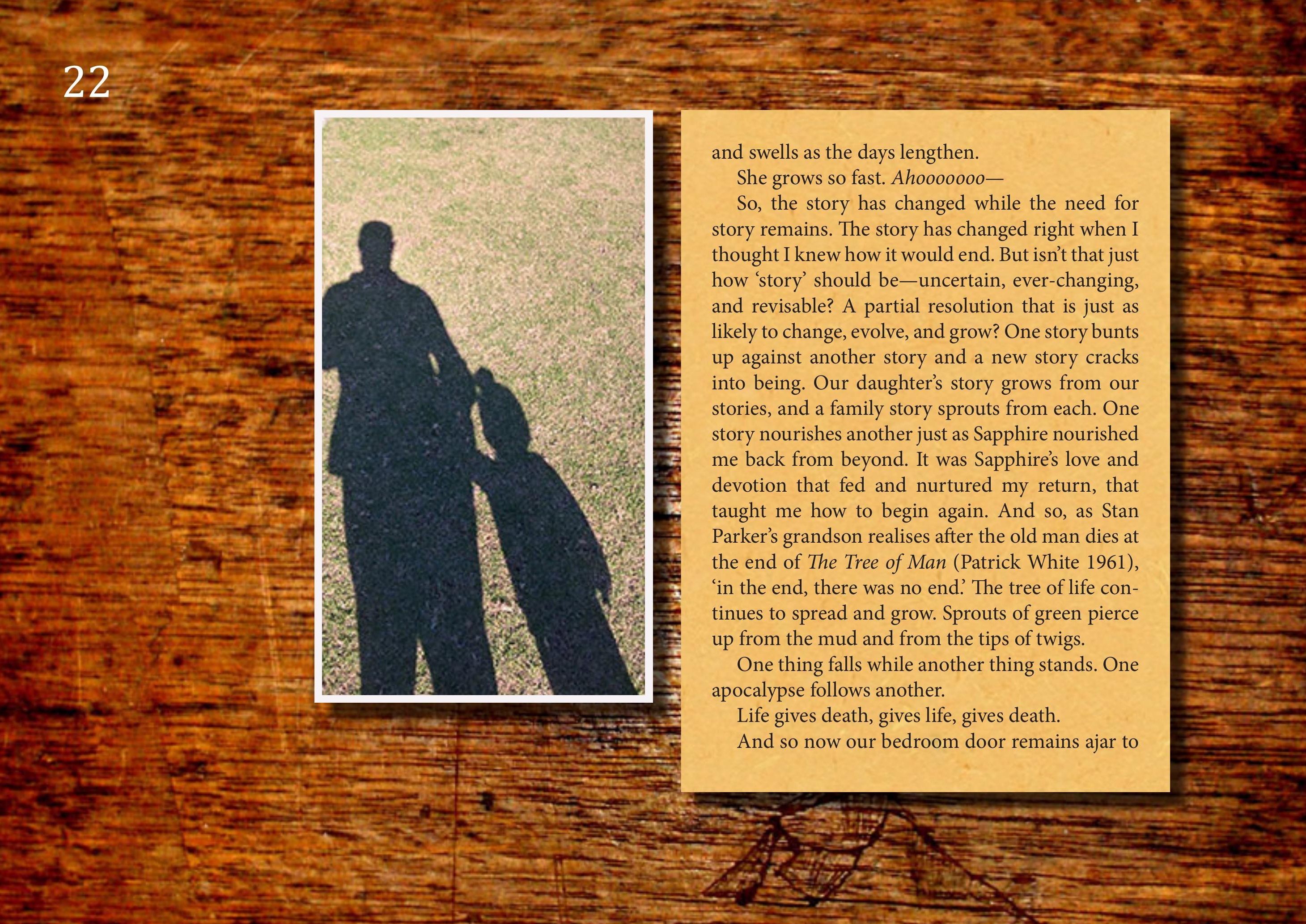




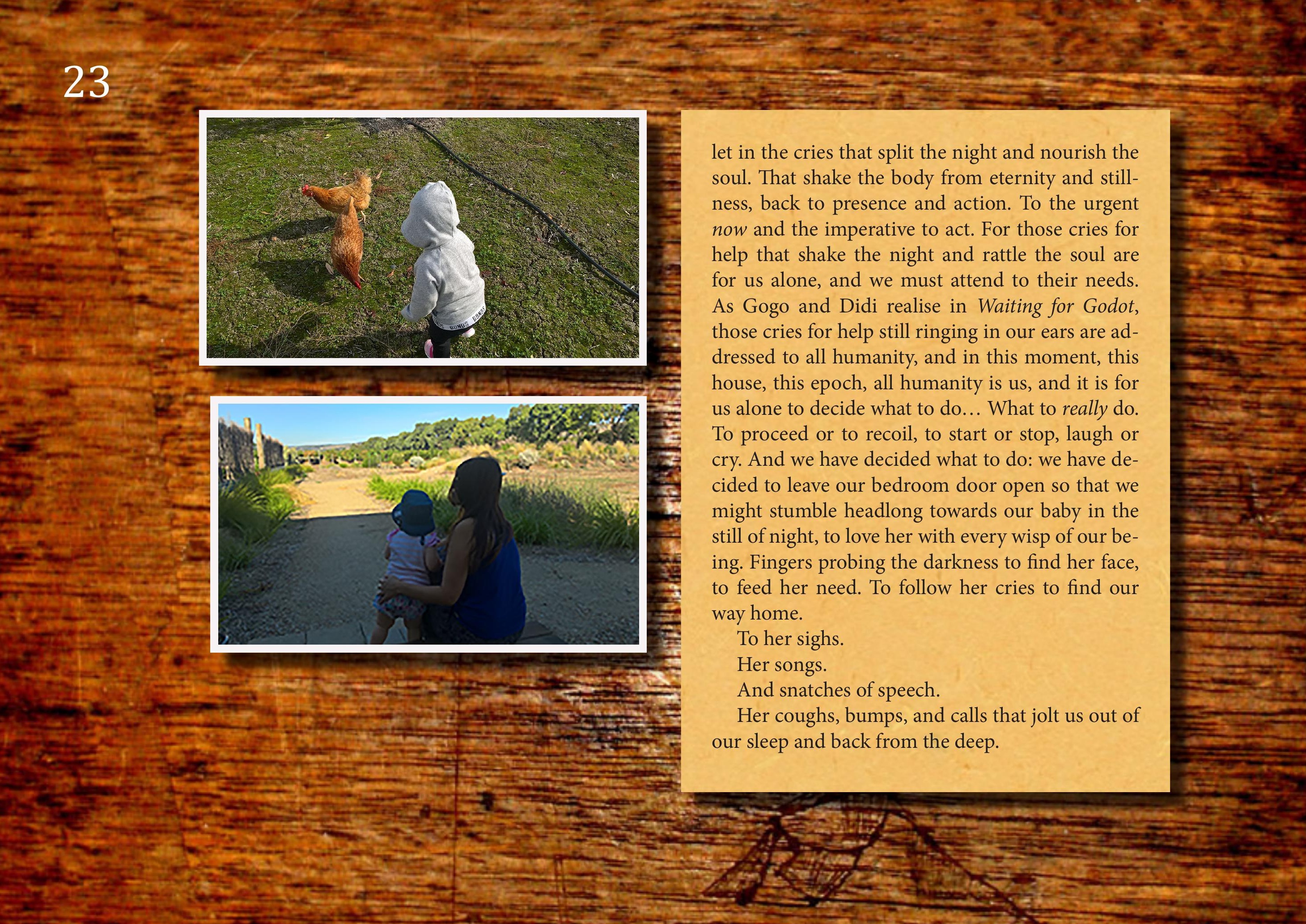




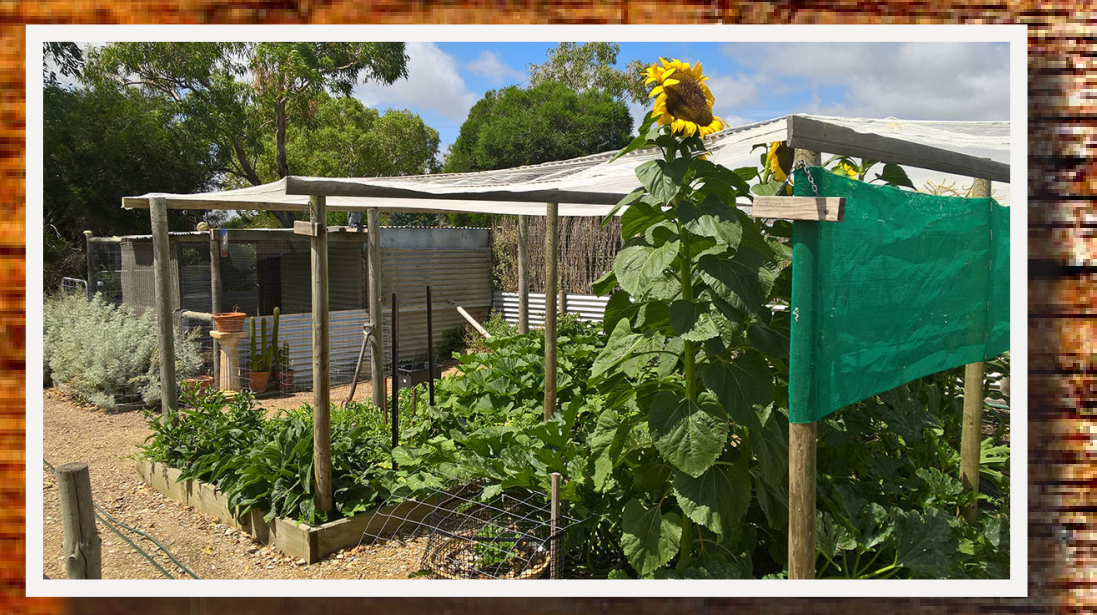

For they are the sound of us. The melody of life.
And, for now and always, that is enough. Because the future is burgeoning with possibility and the void is punctured by cries.

And we are clamouring towards them...

While Sapphire, dear dog, snores in the night.

Ahooooooo-

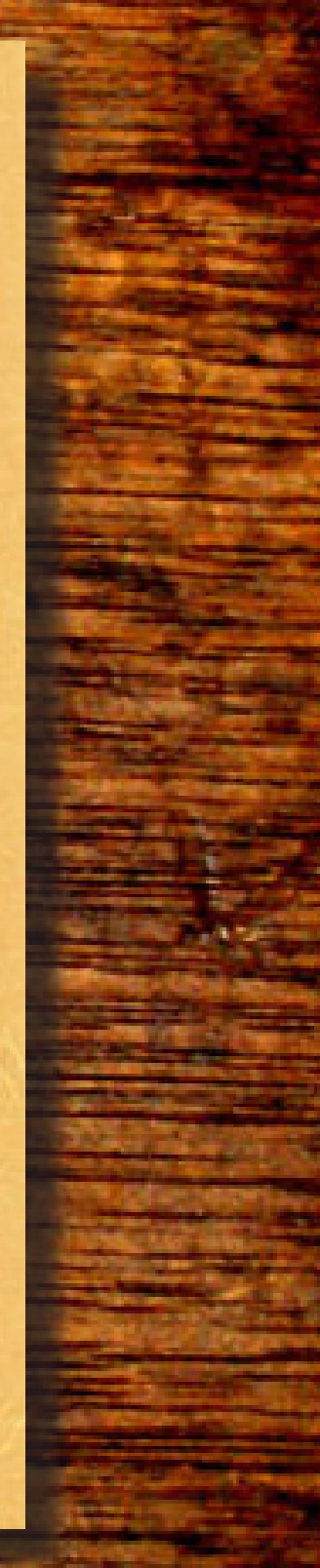

The past is not sealed, not immutable, and it does not belong to anyone. It is an impression left by the telling of stories. I want to invent a world for my mother in which she is free to speak for herself and for her time-to fictionalise her own life. It is what we all do incessantly in an effort to find a personal truth (that glint of gold) to make sense of ourselves and of history-to keep the past open.

(Robyn Davidson, Adelaide Writers' Week, 2 March 2008)

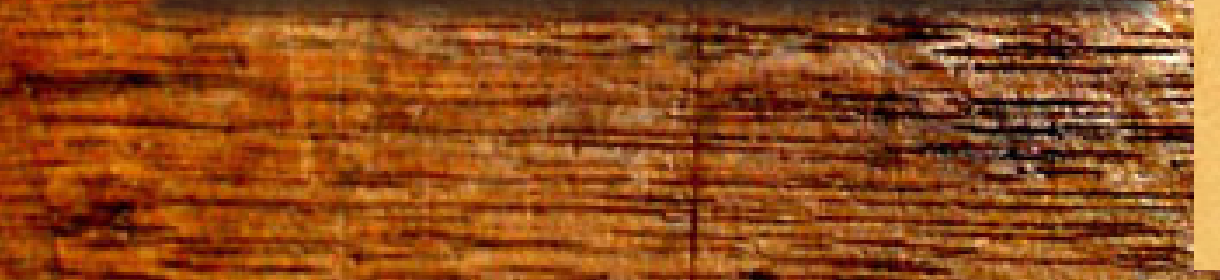


25 


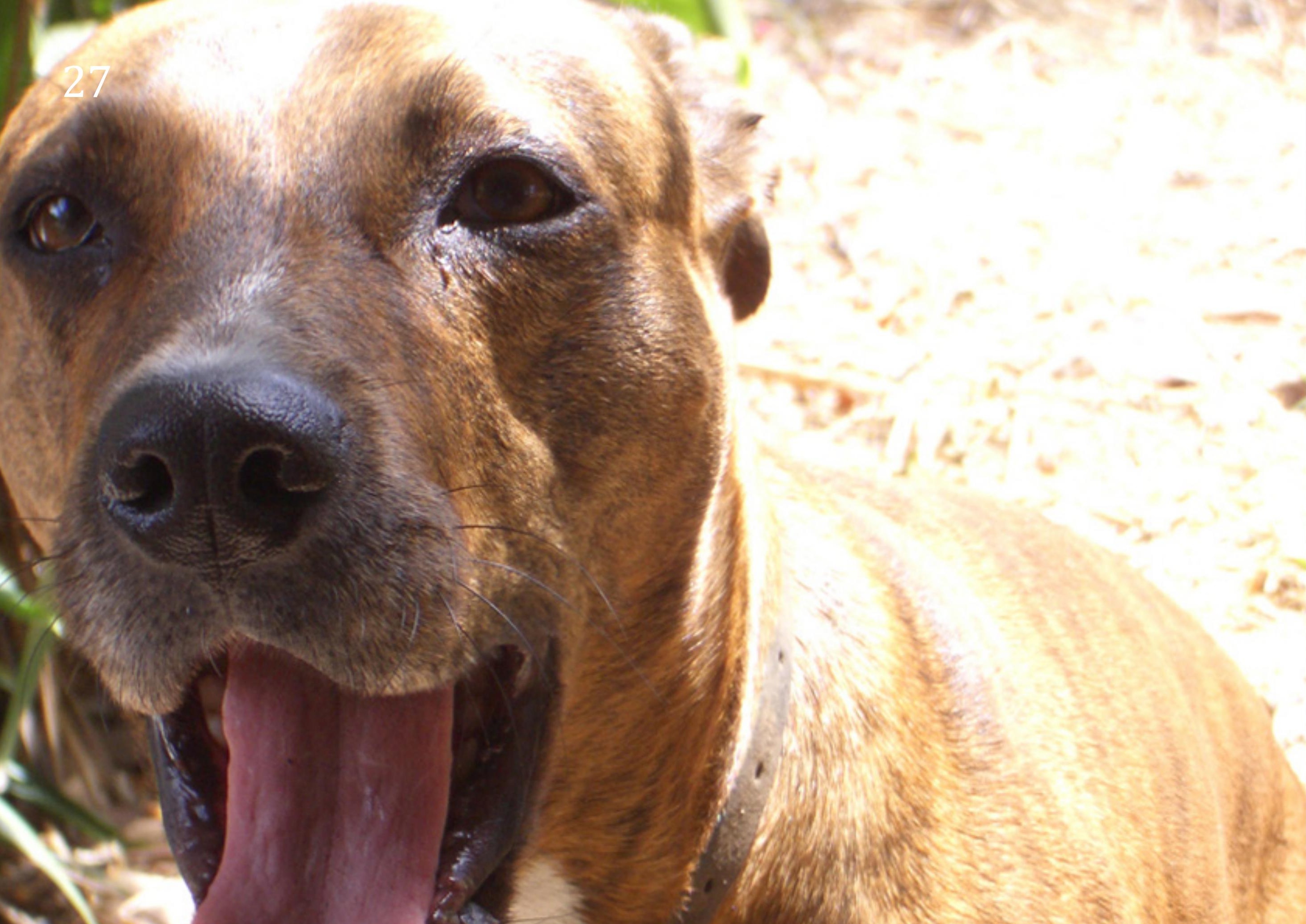




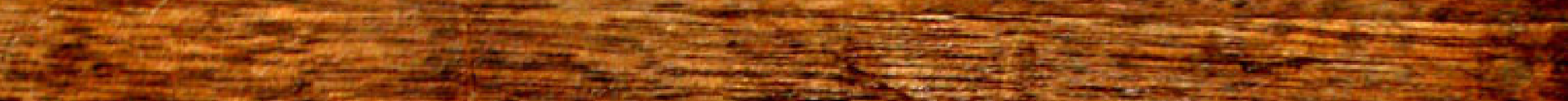

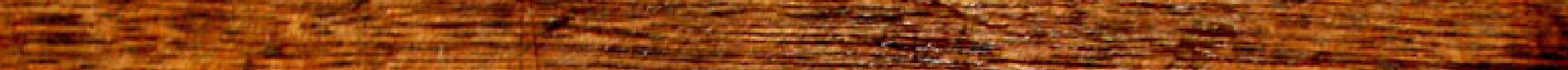

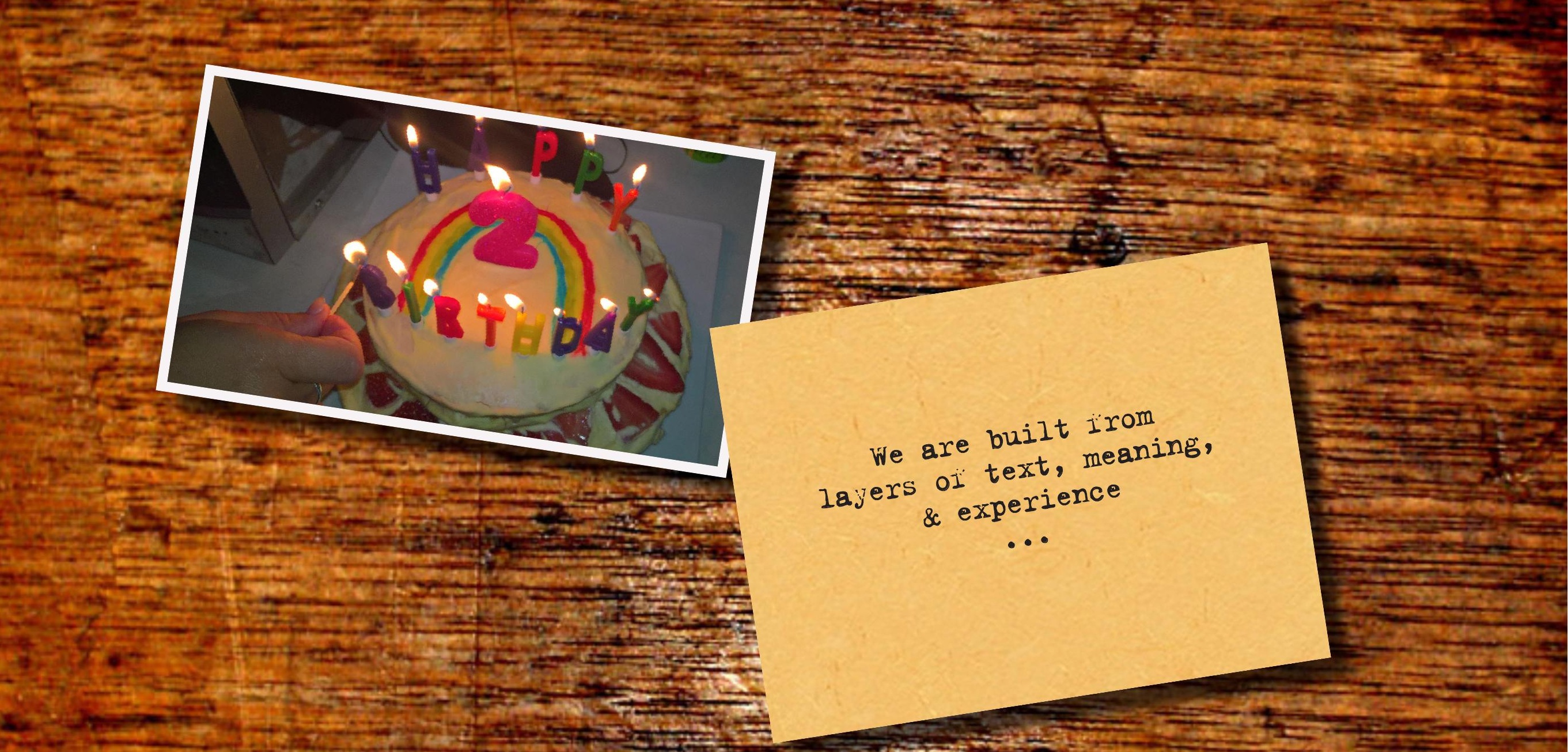

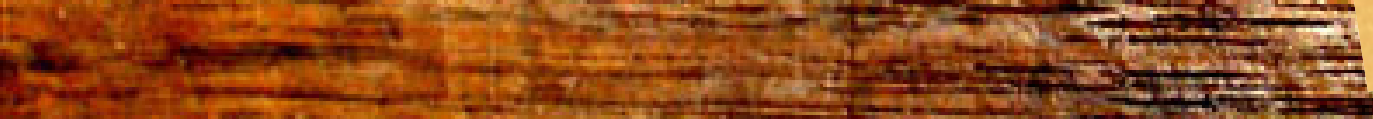

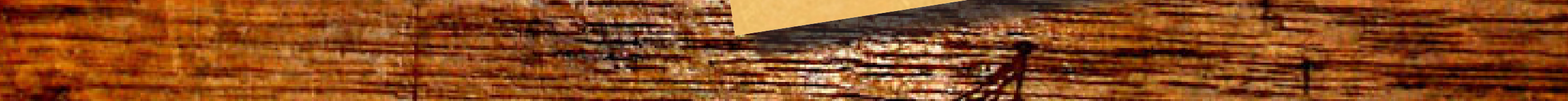

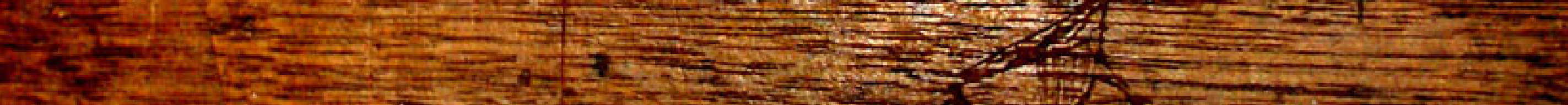

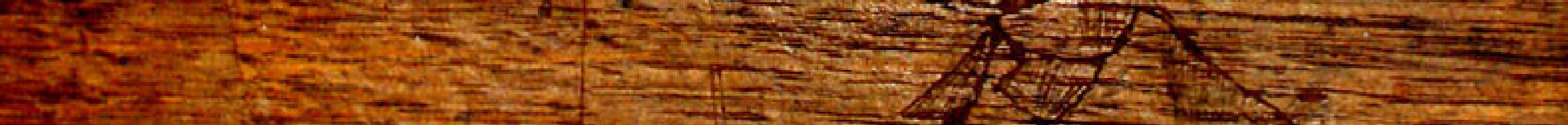




\section{Works cited}

Aarseth, EJ 1997 Cybertext: perspectives on ergodic literature, John Hopkins University Press, Baltimore.

Bauman, Z 1995 Life in fragments: essays in postmodern morality, Blackwell, Oxford.

Bauman, Z 2006 Wasted lives: modernity and its outcasts, Polity Press, Cambridge.

Carter, P 1987 The road to Botany Bay, Faber and Faber, London.

Derrida, J 1976 Of Grammatology (GC Spivak, trans), Johns Hopkins University Press, Baltimore.

Doyle, W and K Carter 2003 'Narrative and learning to teach: implications for teacher-education curriculum, Journal of curriculum studies 3, 2: 129-137.

Ellis, C and AP Bochner 2000 'Autoethnography, personal narrative, reflexivity', in NK Denzin and YS Lincoln (eds), Handbook of qualitative research (2nd ed: 733768), Sage, Thousand Oaks, CA.

Finley, S 2005 'Arts-based inquiry: performing revolutionary pedagogy', in NK Denzin and YS Lincoln (eds), The Sage handbook of qualitative research (3rd ed: 681-694), Sage, Thousand Oaks, CA.

Kristeva, J 1980 Desire in language: a semiotic approach to literature and art (T Gora, A Jardine and LS Roudiez, trans), Columbia University Press, New York.
Lessing, D 1999 The golden notebook. HarperCollins, New York.

Miller, A 2008a 'Pedagondage: touring and drifting in a postmodern age', Creative approaches to research, 1, 2: 94-122.

Miller, A 2008b 'Personalising ethnography: on memory, evidence, and subjectivity: the writing and learning journey', New writing: the international journal for the practice and theory of creative writing, 5, 2: 89-113.

Miller, A 2010 'Grunge blotto', TEXT, 14, 2.

Miller, A 2013 'Mooonscapes and mallee scrub: diaries of a vagabond', European journal of life writing, 2: 31-82.

Obama, B 2008 Barack Obama: dreams from my father, Text Publishing, Melbourne.

Rousseau, J 1979 Reveries of the solitary walker, Penguin, Middlesex.

Snyder, I 1998 Hypertext: the electronic labyrinth, Melbourne University Press, Victoria.

Ulmer, GL 1985 Applied grammatology: post(e)-pedagogy from Jacques Derrida to Joseph Beuys, Johns Hopkins University Press, Baltimore.

Ulmer, GL 2004 Teletheory (2nd ed), Atropos, New York. 


\section{0}

tracks to justify our insiding blinded by a fuward? Perhaps we are rion ultimately lies at our ture whose redemptien misery and confusion backs, in the rubbe, already overcome? that we think we have alture, Identity,
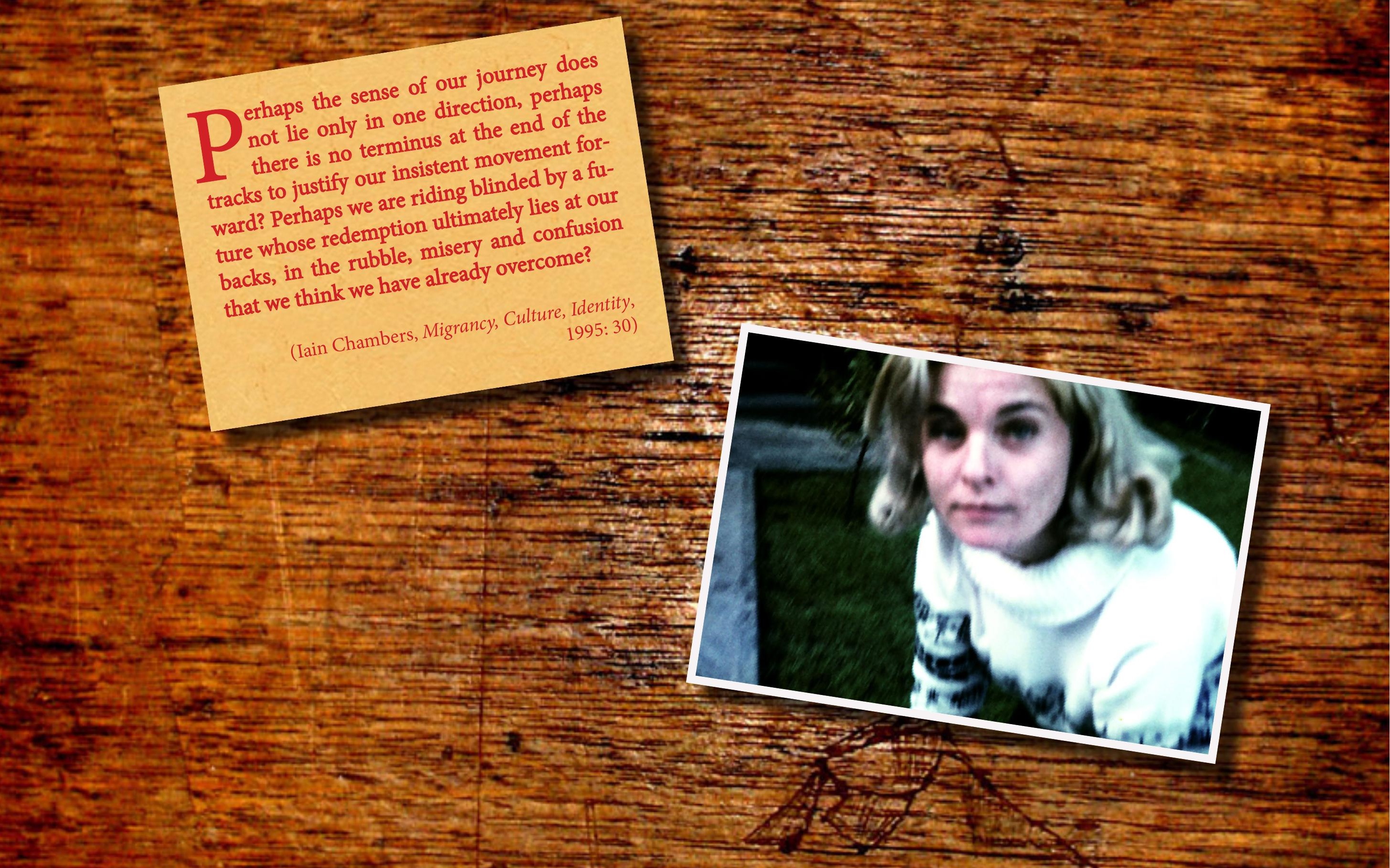